Archived version from NCDOCKS Institutional Repository http://libres.uncg.edu/ir/asu/

Williams, M. (2007). How coverage of death sentences vary: A study of two Ohio newspapers. Journal of Crime and Justice, 30, 53-78. ISSN: 0735-648X DOI:

10.1080/0735648X.2007.9721235

\title{
HOW COVERAGE OF DEATH SENTENCES VARY: A STUDY OF TWO OHIO NEWSPAPERS Marian R. Williams
}

\begin{abstract}
Research on media coverage of crime and justice issues tends to examine the effects of this coverage on public opinion, fear of crime, and other attitudes. Coverage of the death penalty, particularly executions, is a popular topic among researchers, who wish to examine whether deterrence is achieved when media outlets cover executions in the news, The current study examines an underlying, and perhaps overlooked, aspect of this previous research-how consistent is media coverage of these issues? By examining coverage of death sentences, not executions, in two Ohio newspapers, the current study illustrates that coverage of certain crimes-rimes that result in a death sentence-is not similar both between the newspapers and within each newspaper itself: It is argued that conclusions about public attitudes toward crime and justice issues must be tempered by the fact that media coverage of crime, even specific types of crime, is not created equal
\end{abstract}

\section{INTRODUCTION}

Media coverage of the criminal justice system is a popular topic among researchers. This popularity is well-founded, as many believe that the media are able to influence how the public views the world around them. According to Franklin (1999), the media are major sources of information about a number of issues, especially crime and justice. The public has limited experience with various social concerns and, therefore, must rely on media outlets to provide them with information. Graber (1980) claims that the media are the primary outlet for receiving information about crime. Yanich (200 1) argues that public is interested in crime and justice issues because of the "it can happen to you" aspect. Media outlets are able frame these issues to make them more personal 
to the public and to help the public make sense of the world around them. According to Sotirovic (2003), the news media's objective is to present what is rare and unusual, appealing to emotions, instead of delving into the "why" or the "how" of the issue. In fact, some claim that the news media downplay the broader political, economic, and social issues at the root of many problems and focus instead on the individuals involved and how a particular incident affected them (Sotirovic, 2003, Barak, 1994). Gilliam and lyengar (2000) assert that, in some cities, crime news, particularly violent crime, can account for up to 75 percent of all news coverage. As a result, media outlets can have a large influence on public opinion about crime and justice.

\section{LITERATURE REVIEW}

\section{General News Coverage}

As stated earlier, crime news can occupy a good portion of overall news coverage and this varies nationally and locally. According to Surette (1998), crime and justice topics generally comprise about 10-15 percent of all national news coverage, 20 percent of local television news, and about 25 percent of local newspaper coverage. National news coverage of crime (television and newspapers) typically focuses on unusual or heinous crimes, such Timothy McVeigh's bombing of the federal building in Oklahoma City in 1995, and those that feature attractive or celebrity participants, such as the Laci Peterson kidnapping case in 2004 and Michael Jackson's child molestation trial in 2005. Local news also focuses on these cases, but much of the local provides spot coverage of crimes, due to the limited time frame of a newscast. Because of this, it is difficult to provide context or discussion on particular crime and justice issues. Local newspapers are able to provide more detail on such matters and, thus, are perhaps less sensational in their news coverage (see generally, Surette, 1995).

Research that examines media coverage of crime and justice issues typically concerns the social construction of these issues and the public's perception of them. How the media portray certain crimes (usually violent or heinous), certain offenders and victims (e.g., Black offenders, White victims, etc.), or certain criminal justice processes (e.g., the death penalty) likely influences public perceptions (Peelo, Francis, Soothill, Pearson, and Ackerley, 2004; Duwe, 2000). Murders typically gamer the most coverage, but other crimes deemed heinous by the media (and the public), such as rape and child abduction/molestation, will be covered if murders are not as common (Chermak, 1995, Duwe, 2000). Fox and Levin (1998) note that the public vision of murder is entirely different from reality. The media tend to focus on murders that involve strangers, psychopathic 
offenders, or inherently brutal circumstances, none of which are common characteristics of murders. As a result, Fox and Levin (1998) state that this creates an irrational fear of certain crimes that, in reality, do not occur very often.

Research has examined the effect of news coverage on public perceptions regarding fear of crime and the use of punishment. For example, research has generally shown that media coverage has a positive relationship with an individual's fear of crime (see Fox and Levin, 1998, Gerbner and Gross, 1980; Chiricos, Eschholz, and Gertz, 1997; Wortley, Hagan, and MacMillian (1997)) and support for harsher punishment (e.g., Roberts and Doob, 1990). On the other hand, Fan, Keltner, and Wyatt (2002) indicated that media coverage of actual innocence claims in Illinois during the 1990s influenced support for the death penalty; in effect, there was a negative relationship between the number of news stories on the issue and support for the death penalty.

\section{Newspaper Coverage of Homicides and the Death Penalty}

As indicated earlier, homicides usually comprise the largest proportion of stories about crime. However, as Chermak (1998) noted, not all murders are alike, as certain characteristics make some homicides more newsworthy than others. In his study on newspaper coverage of crime coverage in six urban newspapers, Chermak found that the number of victims was the strongest indicator of newspaper coverage, particularly for homicides.

An analysis by Peelo et al. (2004) examined homicide coverage in England and Wales. The authors indicated that not all homicides are the same, and some lead to more outrage than others. As a result, newspapers will report homicides based on what is considered more newsworthy. In their analysis of three national newspapers, the authors found that the newspapers did not report a majority of homicides and that the homicides that were covered provide a distorted picture of reality. The circumstances surrounding the homicide (e.g., whether it was a sexual homicide or one that involved financial gain) was the most significant predictor of whether a homicide would be reported in all three newspapers The authors reported differences, however, in the newspapers' coverage regarding other variables, such as age of victim, whether a shooting was involved, etc., suggesting that each newspaper considered certain elements of the crime differently than the other newspapers, "producing a different picture for their readers" (p. 273).

In a study of homicides featured in the Los Angeles Times, Sorenson, Manz, and Berk (1998) examined the factors that influenced coverage of homicide cases. The authors found that homicides featuring female victims, very young or very old victims, and victims 
who were not known to the offender (strangers) received the most coverage. Additionally, homicides featuring non-white victims, non-strangers, and no guns received the least amount of coverage. This lends further support to the conclusion that not all homicides are treated equally.

An analysis of homicide stories in the Columbus Dispatch was performed by Lundman (2003). The author's primary focus was to examine if certain race-gender combinations of the offender and victim received different coverage. Lundman (2003) found that an uncommon homicide dyad - Black male killing a White female - received the most coverage compared to other dyads. Additionally, other uncommon dyads received coverage - Black males killing White males and White males killing White females. Based on this information, it appears that race of victim plays a large role in coverage of homicides in this newspaper.

Johnstone, Hawkins, and Michener (1 994) examined two Chicago newspapers and their reporting of homicides in 1987. The authors focused on "human interest variables," such as race, gender, age of offender and victim, method used, and area of homicide, to determine which homicides received coverage and, if so, how much. For both these include rare elements of a homicide - white victim, female victim, child victim, multiple offenders. Additionally, each newspaper focused more on certain elements; the Tribune focused more on homicides featuring multiple offenders and rare methods, while the Sun-Times featured homicides with child victims and those occurring in more affluent areas. Thus, the reporting of rare elements of a homicide, and different rare elements by two separate newspapers, provide a picture of homicide to readers that does not reflect reality.

Cases in which the death penalty comes into play are usually considered the most violent and heinous; thus, the media will tend to cover these cases from the beginning. Haney and Greene (2004) performed a content analysis of newspaper coverage of a sample of 26 death-eligible defendants in California. The authors indicated that the newspapers tended to rely on "official" sources of information (police, prosecutors) and to focus on positive aspects of the victim and negative aspects of the defendant. For example, newspapers overwhelmingly focused on defendants' criminal history, drug use, brutality, etc., and tended to gloss over things such as childhood abuse and neglect. This indicates that death penalty coverage is much like coverage of other crime and justice issues.

A popular research topic concerns media coverage and its relationship to a deterrent effect of the death penalty. Deterrence theorists argue that, if deterrence from crime is to work, the public must 
know that there are consequences for criminal acts. Hence, media coverage of executions will provide the public with the image that, if murder occurs, execution can result.

A number of studies have attempted to ascertain if national television coverage of executions has an effect on homicide rates (see Bailey, 1990; Peterson and Bailey, 1994; Stack, 1987). The focus on national news coverage is problematic, however, since most executions receive no national coverage. Peterson and Bailey (1 99 1) indicate that only 25 out of 93 executions between 1976-1987 received any national exposure. Since 1987, over 850 inmates have been executed across the country and, given the limited time frame of national network news coverage, it is impossible to cover even a fraction of these executions. Thus, a focus on national news coverage of executions reveals very little about any deterrent effect they may have.

Due to these problems, a number of studies have focused their attention on local coverage of executions, as most executions tend to be covered locally (Stolzenberg and D'Alessio, 2004). Bailey (1998) studied execution coverage in the largest circulation newspaper in Oklahoma (The Daily Oklahoman) during 1989- 199 1. During this time, Oklahoma executed its first inmate in 25 years, so newspaper coverage of this particular incident was intense. In addition, there were 53 other executions throughout the United States during this time, and the Oklahoma newspaper covered 33 of them. Bailey's (1998) results indicated that increased media coverage coincided with an increase in certain types of homicides, but a decrease in other types, resulting in both a brutalization AND deterrent effect.

Stolzenberg and D' Alessio (2004) examined newspaper coverage of executions in Texas between 1990-1994. The authors assessed the coverage of executions in the Houston Chronicle and found that, during this time period, the newspaper referenced in some way all 52 executions that occurred. Regarding a deterrent effect, despite the fact that all of the executions during this time period were covered, there was no effect on murder incidents.

These above-mentioned studies indicate that not all homicides were covered by the newspapers. Regarding the death penalty, Bailey (1998) mentions that, in his coverage of one newspaper's coverage of executions in Oklahoma, some executions may not be covered in other newspapers in the state. If this is the case, how can a deterrent effect be accurately assessed if all executions are not publicized throughout the state? In Bailey's (1998) research, individuals who read the Daily Oklahoman may very well be deterred while others are not. It could be argued that the death-eligible homicides fit the criteria of the "high 
amplitude" homicide discussed by Johnstone, Hawkins, and Michener (1994)-the type of homicide that is covered more extensively.

However, if these "high amplitude" homicides are not covered by newspapers in the state, how can deterrence then be measured?

In Stolzenberg and D'Alessio's (2004) research, it was noted that the Houston Chronicle covered all 52 executions that occurred in the state during the time period under study. What is not known is the consistency of this coverage. What is the extent of coverage of executions that have no local import? Additionally, how consistent is the coverage of executions that DO have local import? Are these executions treated equally? What is needed is an examination of how the death penalty is covered in the same state by different newspapers; in effect, what do we know about how and the extent to which the same cases are covered by different newspapers? It is not simply a question of whether death penalty issues are covered, but how they are covered. There may not be consistent coverage of homicides involving the death penalty, even if these crimes have local ties. For example, a death- eligible homicide involving one defendant and one victim may receive less coverage than a homicide involving multiple victims.

The current study focuses on aspects of a number of the abovementioned research projects. First, it examines newspaper coverage of a serious crime-homicide-by engaging in a content analysis of 2 different newspapers in Ohio, each from different areas. Newspaper coverage was selected because newspapers provide more in-depth and continuing coverage of the crime event-the crime and the subsequent criminal justice process-instead of just short, spot news coverage typically seen on television. In addition, newspaper coverage is more extensive in that it can cover more homicide incidents than local television news. In addition, the use of newspapers in different areas may shed light on how news is provided given who the editors, publishers, and readers are.

A second aspect of the current study is that it focuses on a small class of homicides-those that received the death penalty-in an effort to assess a larger number of newspaper stories. It could be argued that those homicides that result in a death penalty are covered more extensively by media outlets due to the severity of the crime; in effect, they are the "worst of the worst." On a related note, these homicides are covered up to the sentencing stage, not at execution, as previous studies have done. Executions, especially in Ohio, are rare occurrences themselves, but also in comparison to the imposition of a death sentence-those who are given death sentences vastly outnumber those who are actually executed. Thus, the current study is able to provide a broader examination of death penalty cases by NOT focusing strictly 
on the execution itself.

\section{CURRENT STUDY}

The current study examines newspaper coverage in two urban newspapers in Ohio-Cleveland's Plain Dealer and Cincinnati's Enquirer. These newspapers have penetration beyond the individual cities they represent. The Plain Dealer serves a metropolitan area consisting of eight counties, while the Enquirer contains serves an area that includes five Ohio counties as well as ten counties in Indiana and Kentucky (U.S. Census Bureau, 2000). Thus, when examining death sentences in Ohio, the two newspapers combined cover a local area of thirteen' Ohio counties. In addition, both newspapers contain sections devoted to state news that occurs outside of the cities' metropolitan area.

The Plain Dealer claims a daily circulation (paid subscribers) of just over 350,000 and a Sunday circulation of approximately 476,000 (Audit Bureau of Circulation, 2004). The Enquirer claims a daily circulation of approximately 170,000 and just over 276,000 on Sunday (Newspapers First, 2004). These numbers do not include total readership, which includes non-subscribers who purchase the newspaper from boxes or newsstands. The Enquirer has a sister newspaper, the Post, which is the evening equivalent to the Enquirer's morning edition. Circulation for the Post is small compared to the Enquirer (approximately 40,000) and generally contains the same news stories as the Enquirer. For purposes of this study, the Enquirer was utilized for analysis since it has the larger circulation of the two and utilization of both the Post and Enquirer would result in duplication of news stories. Although the combined circulation of the Post and Enquirer is higher, the fact that both newspapers contain the same stories written by the same reporters led the author to analyze the Enquirer only, as readers typically do not subscribe to both the morning and evening editions of newspapers. Thus, it could be argued that the Enquirer's stories have a longer reach than its circulation numbers indicate, since the Enquirer's stories are found in the Post.

The metropolitan areas that these newspapers serve are similar in some respects. Both Cleveland and Cincinnati have a high black population in the urban core (US. Census Bureau, 2000). Population declines have struck both cities, although Cleveland's declines are more substantial. Despite this, there are differences between the areas. The median income for the Cleveland metropolitan area is lower than the median income for the Cincinnati metropolitan area $(\$ 44,000$ compared to $\$ 50,000$, respectively) (U.S. Census Bureau, 1997, 2000). In addition, a report by the Citizens for Civic Renewal in Cincinnati (2001) stated that the city has "some of the most pronounced patterns 
of separation by race and income in the nation" as the white, more affluent residents left the city for the suburbs. Cincinnati has also experienced issues with race relations, stemming from police shootings of black suspects (see generally Hulsey, 2001 ). Additionally, the political demographics served by the two newspapers are quite different. The Plain Dealer serves an area that has democratic leanings (see generally, Free Press, 2004), while the Enquirer serves a largely conservative area (see generally, City Beat, 2000). The primary reasons for the selection of these newspapers are twofold. First, approximately sixty percent of those on death row during the years of the study committed their crimes in one of the local counties covered by the newspapers. The second reason involves potential differences between the cities and their respective newspapers. As mentioned above, both cities have experienced a population decline, but there are differences between the two cities. Additionally, will the race issues in Cincinnati area affect the Enquirer's coverage? If so, what does this mean for deterrence research and other research that gauges public attitudes and perceptions of the death penalty? It should be noted that this study is not an examination of the political ideologies of the newspapers and how ideology may shape news coverage. Simply, this study examines IF coverage is different between the two newspapers and the implications of these differences (if any) on future research on media coverage, deterrence, and public perception.

\section{METHOD}

The process of analysis of both newspapers was identical. First, information was gathered about individuals sentenced to death between the years of 1981, when Ohio re-instated the death penalty, and 2004. This includes those offenders who were originally sentenced to death, but who were taken off of death row due to some reason - e.g., death, court order, commutation, etc. This information was provided by the Office of the Ohio Public Defender. The data contained demographic information about the offender and victim(s), some characteristics of the offense (e.g., multiple victims) and the date of the offense and sentence. Other characteristics of the offense (e.g., attendant felony circumstances, stranger vs. non-stranger) were compiled from the website of the Ohio Department of Rehabilitation and Correction or from newspaper stories that reported trial information.

Second, newspaper articles were searched based on the on-line index of articles that both newspapers provide. Information that could not be gathered through this index was taken from newspaper archives found at the university's library. Information was gathered about cases from the very beginning of the case - as soon as the defendant was named a suspect - through the imposition of the death sentence and 
beyond. All news stories were included. The news indices were searched based on the defendant's name and/or the victim's name. Unlike previous research, which focused extensively on features such as headlines, column inches, language, etc., the current study coded general information regarding other features. The reason for coding this general information is that it is acknowledged by previous research that newspaper stories of crime and justice issues are similar - eye-catching language, longer stories, rare or lurid details, etc. - so it was expected that both newspapers under study would be no different from the previous studies or from each other. In fact, when assessing headlines and language used in both newspapers, it appears that the newspapers are similar to one another in their use of headlines, language, etc. Both newspapers tended to utilize simple, fact-based headlines when reporting on the case process-"Grant May Face Death" (Cleveland Plain Dealer), "Cook Pleads Not Guilty" (Cincinnati Enquirer). On the other hand, each newspaper occasionally provided a human interest element to a case, interviewing the victim's family or focusing on the effect of the crime, etc. These stories were more likely to contain expressive language in both newspapers: "Violence Stuns, Worries City" (Cleveland Plain Dealer), "Child Relives Fiery, Fatal Night" (Cincinnati Enquirer). Also, both newspapers were apt to characterize a defendant as a "killer," "slayer," or "ex-con," police were often commended for "doing a fine job" or "nabbing a killer," and victims' families were characterized as "grief-stricken" or "mournful." Because of these similarities between the newspapers, the current study focuses on whether the newspapers covered death sentence cases at all and if there were meaningful differences between the coverage.

The total number of defendants who received death sentences during the period was 281-this included death sentences in which one offender killed multiple victims or multiple offenders killed one victim One of the issues involved the coding of multiple victim homicides. Newspaper coverage of cases such as these featured one story with all Victim/offenders mentioned. Thus, each death sentence individually could not be meshed with the newspaper data. For instance, if one defendant kills three victims, these are three individual death sentences. However, newspapers do not publish a separate story for each individual victim. Let us say that there are 50 total news stories on this death sentence case. If each victim appears in each story, there are still only 50 stories about the case, not 150 (three victims $\times 50$ stories each). Thus, multiple victim cases were condensed into one defendant-one victim cases, with the most "aggravated" victim representing the case. For example, if the characteristics of the three victims in the examples above are white male, black male, and white female, the characteristics of the white female homicide were utilized, since white female homicides may be considered more troubling to the public (see 
generally, Holcomb, Williams, and Demuth, 2004). The entire death sentence database was reconstructed in this way, keeping homicides involving white, female, young $(<12)$, or old $(>70)$ victims, or a combination of any of these. This method of condensing the database was taken from death penalty research by Gross and Mauro (1 989), who found that certain factors in multiple homicides affect the treatment of all homicides in the incident. Table 1 provides information on these and other variables under study.

Table 1

Characteristics of Death Sentences under Study

\begin{tabular}{|c|c|c|c|}
\hline & Ohio & Cleveland & Cincinnati \\
\hline \multicolumn{4}{|l|}{ Defendant Race } \\
\hline White $(0)$ & $52 \%(145)$ & $53 \%(46)$ & $48 \%(34)$ \\
\hline Non-White (1) & $48 \%(136)$ & $47 \%(41)$ & $52 \%(37)$ \\
\hline \multicolumn{4}{|l|}{ Defendant Gender } \\
\hline Female (0) & $2 \%(5)$ & $0 \%(0)$ & $6 \%(4)$ \\
\hline Male (1) & $98 \%(276)$ & $100 \%(87)$ & $94 \%(67)$ \\
\hline \multicolumn{4}{|l|}{ Defendant Age $<25$} \\
\hline No $(0)$ & $66 \%(186)$ & $69 \%(60)$ & $66 \%(47)$ \\
\hline Yes (1) & $34 \%(95)$ & $31 \%(27)$ & $34 \%(24)$ \\
\hline \multicolumn{4}{|l|}{ Race of Victim } \\
\hline White $(0)$ & $74 \%(208)$ & $66 \%(57)$ & $68 \%(48)$ \\
\hline Non-White (1) & $26 \%(73)$ & $34 \%(30)$ & $32 \%(23)$ \\
\hline \multicolumn{4}{|l|}{ Gender of Victim } \\
\hline Female (0) & $53 \%(150)$ & $52 \%(45)$ & $54 \%(38)$ \\
\hline Male (1) & $47 \%(131)$ & $48 \%(42)$ & $46 \%(33)$ \\
\hline \multicolumn{4}{|l|}{ Victim age $<12$ or $>70$} \\
\hline No $(0)$ & $78 \%(220)$ & $81 \%(70)$ & $79 \%(56)$ \\
\hline Yes (1) & $22 \%(61)$ & $19 \%(17)$ & $21 \%(15)$ \\
\hline \multicolumn{4}{|l|}{ Defendant-Victim } \\
\hline \multicolumn{4}{|l|}{ Relationship } \\
\hline Stranger $(0)$ & $54 \%(151)$ & $53 \%(46)$ & $52 \%(37)$ \\
\hline Non-Stranger (1) & $46 \%(130)$ & $47 \%(41)$ & $48 \%(34)$ \\
\hline \multicolumn{4}{|l|}{ Weapon Used } \\
\hline Gun $(0)$ & $52 \%(145)$ & $59 \%(51)$ & $41 \%(29)$ \\
\hline Non-Gun (1) & $48 \%(136)$ & $41 \%(36)$ & $59 \%(42)$ \\
\hline \multicolumn{4}{|l|}{ Multiple Victims } \\
\hline No $(0)$ & $73 \%(205)$ & $72 \%(63)$ & $78 \%(55)$ \\
\hline Yes (1) & $27 \%(76)$ & $28 \%(24)$ & $22 \%(16)$ \\
\hline
\end{tabular}




\begin{tabular}{|c|c|c|c|}
\hline \multicolumn{4}{|l|}{$\begin{array}{l}\text { Table } 1 \text { cont'd } \\
\text { Felony Circumstances }\end{array}$} \\
\hline No $(0)$ & $19 \%(54)$ & $22 \%(19)$ & $16 \%(11)$ \\
\hline Yes (1) & $81 \%(227)$ & $78 \%(68)$ & $85 \%(60)$ \\
\hline \multicolumn{4}{|l|}{ Local Case } \\
\hline No $(0)$ & & $69 \%(194)$ & $75 \%(210)$ \\
\hline Yes (1) & & $31 \%(87)$ & $25 \%(71)$ \\
\hline \multicolumn{4}{|l|}{ Interracial Homicide } \\
\hline No $(0)$ & $72 \%(203)$ & $77 \%(67)$ & $75 \%(53)$ \\
\hline Yes (1) & $23 \%(78)$ & $23 \%(20)$ & $25 \%(18)$ \\
\hline $\mathrm{N}$ & 281 & 87 & 71 \\
\hline
\end{tabular}

Table 2

Coverage of Non-Local Death Sentences

\begin{tabular}{|c|c|c|}
\hline & Cleveland Plain Dealer & Cincinnati Enquirer \\
\hline $\begin{array}{l}\text { Number of Non-Local } \\
\text { Death Sentences }\end{array}$ & 194/281 Total & $210 / 281$ Total \\
\hline \multicolumn{3}{|c|}{ Any Story ( $\%$ of non-local death sentences) } \\
\hline No & $92(47 \%)$ & 191 (91\%) \\
\hline Yes & $102(53 \%)$ & $19(9 \%)$ \\
\hline \multicolumn{3}{|l|}{ Total Number of Stories } \\
\hline & 686 & 171 \\
\hline $\begin{array}{r}\text { Mean per Death } \\
\text { Sentence }\end{array}$ & 3.54 & .81 \\
\hline \multicolumn{3}{|c|}{ Number of Stories on Front Page } \\
\hline $\begin{array}{r}\mathrm{n}(\% \text { of total } \mathrm{n} \text { of } \\
\text { stories })\end{array}$ & $36(5 \%)$ & $10(6 \%)$ \\
\hline $\mathrm{n}$ of Non-Local DS (\%) & $12(6 \%)$ & $6(3 \%)$ \\
\hline \multicolumn{3}{|l|}{$\begin{array}{l}\text { Number of Stories in } \\
\text { Section } A\end{array}$} \\
\hline $\begin{array}{r}\mathrm{n}(\% \text { of total } \mathrm{n} \text { of } \\
\text { stories })\end{array}$ & $137(20 \%)$ & $2(1 \%)$ \\
\hline \multicolumn{3}{|l|}{$\begin{array}{l}\text { Number of Stories in } \\
\text { Section B }\end{array}$} \\
\hline $\begin{array}{r}\mathrm{n}(\% \text { of total } \mathrm{n} \text { of } \\
\text { stories })\end{array}$ & $350(51 \%)$ & $58(34 \%)$ \\
\hline \multicolumn{3}{|l|}{$\begin{array}{l}\text { Number of Stories in } \\
\text { Section } C, D\end{array}$} \\
\hline $\begin{array}{r}n(\% \text { of total } n \text { of } \\
\text { stories })\end{array}$ & $116(17 \%)$ & $46(27 \%)$ \\
\hline
\end{tabular}




\begin{tabular}{|c|c|c|}
\hline $\begin{array}{r}\mathrm{n}(\% \text { of total } \mathrm{n} \text { of } \\
\text { stories) }\end{array}$ & $47(7 \%)$ & $55(32 \%)$ \\
\hline \multicolumn{3}{|c|}{$\begin{array}{l}\text { Any Coverage of Pre-Trial Proceedings (\% of non- } \\
\text { local ds) }\end{array}$} \\
\hline No & $144(74 \%)$ & $197(94 \%)$ \\
\hline Yes & $50(26 \%)$ & $13(6 \%)$ \\
\hline \multicolumn{3}{|c|}{ Any Coverage of Witness Testimony } \\
\hline No & $177(91 \%)$ & $207(99 \%)$ \\
\hline Yes & $17(9 \%)$ & $3(1 \%)$ \\
\hline \multicolumn{3}{|c|}{ Any Coverage of Police Besides Arrest } \\
\hline No & $183(94 \%)$ & $208(99 \%)$ \\
\hline Yes & $11(6 \%)$ & $2(1 \%)$ \\
\hline \multicolumn{3}{|l|}{ Any coverage about Victim } \\
\hline No & $177(91 \%)$ & $207(99 \%)$ \\
\hline Yes & $17(9 \%)$ & $3(1 \%)$ \\
\hline \multicolumn{3}{|c|}{ Any Coverage about Victim's Family } \\
\hline No & $177(91 \%)$ & $206(98 \%)$ \\
\hline Yes & $17(9 \%)$ & $4(2 \%)$ \\
\hline \multicolumn{3}{|c|}{ Any Editorials about the Case } \\
\hline No & $192(99 \%)$ & $210(100 \%)$ \\
\hline Yes & $2(1 \%)$ & \\
\hline \multicolumn{3}{|l|}{ Any Coverage of Appeal } \\
\hline No & $157(81 \%)$ & $199(95 \%)$ \\
\hline Yes & $37(19 \%)$ & $11(5 \%)$ \\
\hline
\end{tabular}

\section{RESULTS}

The first set of analyses examined coverage of death sentences that were not of local import. The purpose of this was to gauge the difference in coverage of death sentences that are non-local vs. local and compare the coverage of the newspapers. Table 2 provides the results of this analysis. Most death sentences were not local to Cleveland or Cincinnati individually (although, combined, they represent the majority), so one would expect that coverage of these death sentences would not be as substantial as coverage of local cases (these will be covered shortly). Examining Table 2, it appears that Cleveland's Plain Dealer published at least one story in 53 percent of non-local death sentences, compared to only 9 percent for Cincinnati's Enquirer. Cleveland's Plain Dealer also published more stories on non-local death sentences compared to Cincinnati's Enquirer (686 to 171, respectively). At first blush, it appears that the Plain Dealer provides more extensive coverage of non-local death sentences than the Enquirer, giving its readers a flavor of what is occurring in other areas of the state. 
Table 3

Coverage of Local Death Sentences

\begin{tabular}{|c|c|c|}
\hline & Cleveland Plain Dealer & Cincinnati Enquirer \\
\hline $\begin{array}{l}\text { Number of-Local } \\
\text { Death Sentences }\end{array}$ & $87 / 281$ Total & $71 / 281$ Total \\
\hline \multicolumn{3}{|c|}{ Any Story (\% of local death sentences) } \\
\hline No & $11(13 \%)$ & $2(3 \%)$ \\
\hline Yes & $76(87 \%)$ & $69(97 \%)$ \\
\hline \multicolumn{3}{|l|}{ Total Number of Stories } \\
\hline stories) & 1214 & 1430 \\
\hline $\begin{array}{r}\text { Mean per Death } \\
\text { Sentence }\end{array}$ & 13.95 & 20.13 \\
\hline \multicolumn{3}{|c|}{ Number of Stories on Front Page } \\
\hline $\begin{array}{r}n(\% \text { of total } n \text { of } \\
\text { stories })\end{array}$ & $141(12 \%)$ & $185(13 \%)$ \\
\hline $\mathrm{n}$ of Local DS (\%) & $35(40 \%)$ & $39(55 \%)$ \\
\hline \multicolumn{3}{|l|}{$\begin{array}{l}\text { Number of Stories in } \\
\text { Section A }\end{array}$} \\
\hline $\begin{array}{r}n \text { (\% of total } n \text { of } \\
\text { stories })\end{array}$ & $117(10 \%)$ & $78(5 \%)$ \\
\hline \multicolumn{3}{|l|}{$\begin{array}{l}\text { Number of Stories in } \\
\text { Section B }\end{array}$} \\
\hline $\begin{array}{r}\mathrm{n}(\% \text { of total } \mathrm{n} \text { of } \\
\text { stories) }\end{array}$ & $725(60 \%)$ & $542(38 \%)$ \\
\hline \multicolumn{3}{|l|}{$\begin{array}{l}\text { Number of Stories in } \\
\text { Section } C, D\end{array}$} \\
\hline $\begin{array}{r}\mathrm{n} \text { (\% of total } \mathrm{n} \text { of } \\
\text { stories) }\end{array}$ & $107(9 \%)$ & $625(44 \%)$ \\
\hline
\end{tabular}




\begin{tabular}{|c|c|c|}
\hline $\begin{array}{r}\text { Number of Stories in } \\
\text { Section } E, F, G \\
\mathrm{n}(\% \text { of total } \mathrm{n} \text { of } \\
\text { stories })\end{array}$ & $124(10 \%)$ & $0(0 \%)$ \\
\hline \multicolumn{3}{|c|}{$\begin{array}{l}\text { Any Coverage of Pre-Trial Proceedings (\% of local } \\
d s)\end{array}$} \\
\hline $\begin{array}{r}\text { No } \\
\text { Yes }\end{array}$ & $\begin{array}{l}21(24 \%) \\
66(76 \%)\end{array}$ & $\begin{array}{l}11(16 \%) \\
160(84 \%)\end{array}$ \\
\hline \multicolumn{3}{|c|}{ Any Coverage of Witness Testimony } \\
\hline No & $60(69 \%)$ & $36(51 \%)$ \\
\hline Yes & $27(31 \%)$ & $35(49 \%)$ \\
\hline \multicolumn{3}{|c|}{ Any Coverage of Police Besides Arrest } \\
\hline No & $73(84 \%)$ & $41(58 \%)$ \\
\hline Yes & $14(16 \%)$ & $30(42 \%)$ \\
\hline \multicolumn{3}{|l|}{ Any coverage about Victim } \\
\hline No & $61(70 \%)$ & $37(52 \%)$ \\
\hline Yes & $26(9 \%)$ & $34(48 \%)$ \\
\hline \multicolumn{3}{|c|}{ Any Coverage about Victim's Family } \\
\hline No & $66(76 \%)$ & $41(58 \%)$ \\
\hline Yes & $21(24 \%)$ & $30(42 \%)$ \\
\hline \multicolumn{3}{|c|}{ Any Editorials about the Case } \\
\hline No & $85(98 \%)$ & $70(>99 \%)$ \\
\hline Yes & $2(2 \%)$ & $1(<1 \%)$ \\
\hline \multicolumn{3}{|l|}{ Any Coverage of Appeal } \\
\hline No & $32(37 \%)$ & $16(23 \%)$ \\
\hline Yes & $55(63 \%)$ & $55(77 \%)$ \\
\hline
\end{tabular}

Regarding placement of stories, for both newspapers, section A was devoted to national, international, and "high priority" local and state news. Section $B$ generally covered lower priority local and state news, while sections C, D, E, F, and G (if applicable) were generally devoted to sports, lifestyles, and other national, international, state, and local news that was not covered in previous sections. For both of the newspapers under study, a majority of stories were published in sections $B$ through $G$, suggesting that non-local death sentences were not receiving high priority coverage by the newspapers. It should be noted, however, that Cleveland's Plain Dealer did feature a much higher percentage of stories in section A ( $20 \%$ of all non-local stories), while Cincinnati's Enquirer published a majority of its stories in sections C, D, E, F, and G (59\% of all non-local stories). This suggests that the Plain Dealer gave slightly higher priority coverage of nonlocal death sentences compared to the Enquirer.

Regarding types of stories published by the newspapers, overall, neither newspaper went into too much detail about cases. However, Cleveland's Plain Dealer provided slightly more coverage of the case 
process than Cincinnati's Enquirer. Since the Plain Dealer published more stories than the Enquirer, it should come as no surprise that it features more stories about the case process. It could be said that readers of the Plain Dealer are provided more information about nonlocal death sentences than readers of the Enquirer.

Table 4

\section{Characteristics of Stories Published-Any Story}

\begin{tabular}{|c|c|c|c|}
\hline \multirow[t]{2}{*}{ Cleveland Plain Dealer } & \multirow[b]{2}{*}{ B } & \multirow[b]{2}{*}{ S.E. } & \multirow[b]{2}{*}{$\begin{array}{l}\text { Odds } \\
\text { Ratio }\end{array}$} \\
\hline & & & \\
\hline Defendant Race & -1.726 & .975 & $.178^{*}$ \\
\hline Defendant Gender & -1.789 & 1.184 & .167 \\
\hline Defendant Age $<25$ & .308 & .314 & 1.360 \\
\hline Victim Race & 1.241 & .994 & 3.459 \\
\hline Victim Gender & -.165 & .300 & .848 \\
\hline Victim Age $<12$ or $>70$ & .081 & .347 & 1.084 \\
\hline Relationship & -.544 & .301 & $.580^{*}$ \\
\hline Weapon Used & -.264 & .299 & .768 \\
\hline Multiple Victims & .402 & .347 & 1.495 \\
\hline Felony Circumstances & .122 & .371 & 1.129 \\
\hline Local Homicide & 1.925 & .369 & $6.852^{* *}$ \\
\hline Interracial Homicide & 1.678 & .973 & $5.357^{*}$ \\
\hline Constant & 2.068 & 1.285 & 7.908 \\
\hline \multicolumn{4}{|c|}{$\begin{array}{l}\text { Model Chi-Square }=50.547, P<.000 \\
-2 \text { Log Likelihood }=318.739 \\
* * p<.01 \\
{ }^{*} p<.05 \\
n=281\end{array}$} \\
\hline
\end{tabular}




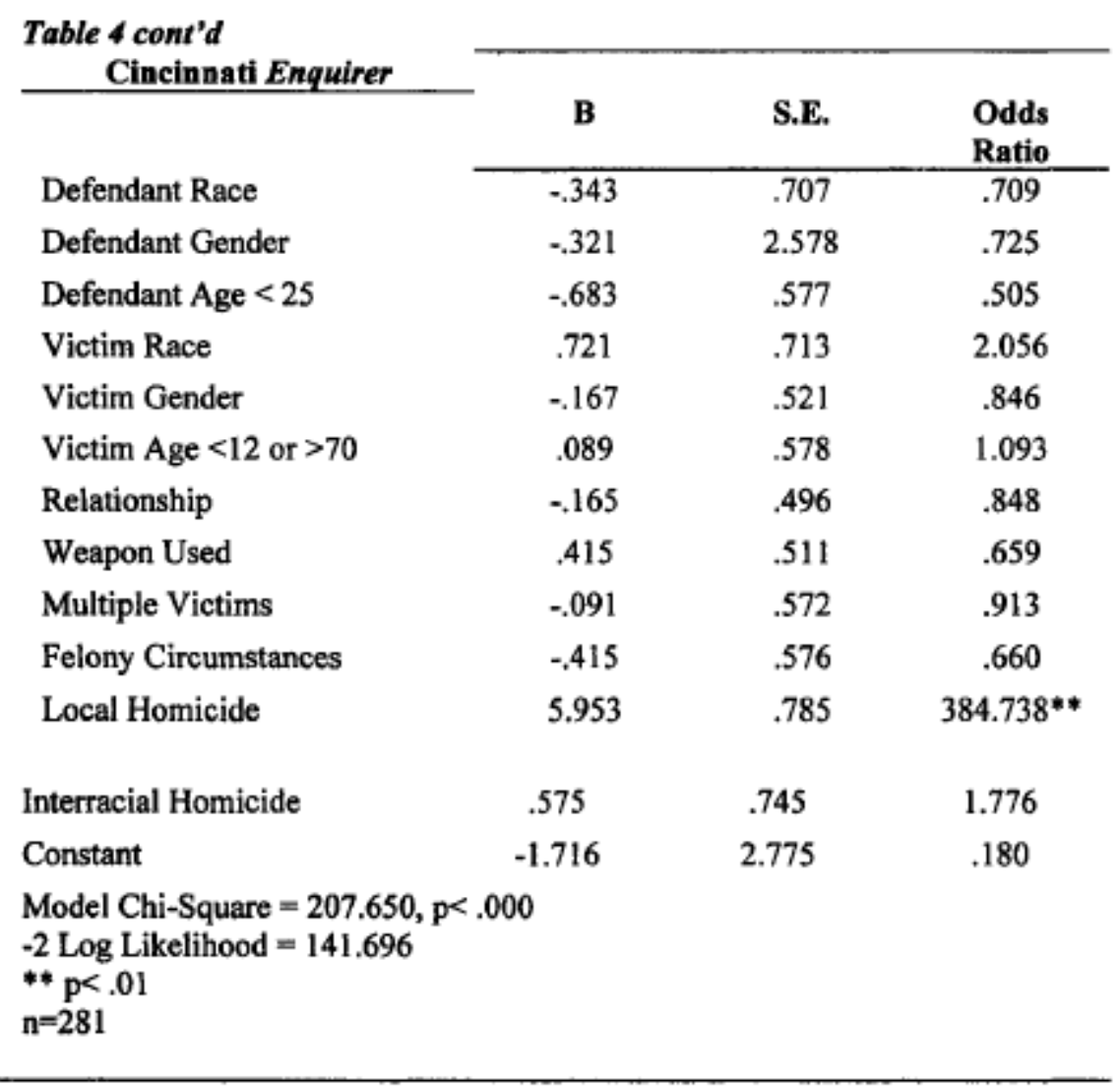

The second set of analyses examines coverage of local death sentences. Table 3 illustrates, not surprisingly, that coverage of local death sentences is much more extensive than coverage of non-local cases, for both newspapers. First, of interest is percentage of local death sentences that were not covered by the newspapers - 13 percent (1 1 cases) for Cleveland's Plain Dealer and 3 percent (2 cases) for Cincinnati's Enquirer). Common sense would indicate that newspapers would cover all of their local death sentence cases but, apparently, this does not play out in these newspapers. As a result, readers are not given $A N Y$ information about a handful of death sentence cases that have occurred in their local area.

Regarding the total number of stories published, Cincinnati's Enquirer published more stories overall and more stories per death sentence than Cleveland's Plain Dealer. Regarding placement of stories, both newspapers increased their front page coverage when local death sentence cases are involved, each published about the same percentage of these cases on the front page. In other sections, Cincinnati's Enquirer publishes the bulk of its stories in sections B, C, and D ( $82 \%$ of all stories), while Cleveland's Plain Dealer publishes the bulk of its stories in sections A and B ( $70 \%$ of all stories). Thus, although the Enquirer publishes more stories, the Plain Dealer 
publishes more of its stories in the more visible, higher priority sections of the newspaper.

As for types of stories about local death sentence cases, as expected, both newspapers greatly increased coverage of the case process. Cincinnati's Enquirer provided more coverage of the case process across the board than Cleveland's Plain Dealer. It could be argued that the Enquirer coverage is more local-centric, focusing predominantly on local cases and providing more extensive and detailed information about these cases to its readers.

Table 4 provides a logistic regression analysis of characteristics of cases that result in at least one story being published about it. The included variables feature both legal and extra-legal information in order to gauge whether certain characteristics of death sentence cases make those cases more newsworthy than others. The analyses include all death sentences statewide, controlling for locality, in order to provide a large enough $\mathrm{n}$ for examination. For the Cleveland Plain Dealer, local death sentences were more likely to have at least one story published about them (odds ratio $=6.852, p<. \mathrm{OOI}$ ) than non-local cases. Regarding other variables, death sentences involving non-white defendants and a non-stranger relationship are less likely to have a story published about them (though the significance for both is only $p<$.O5). Additionally, death sentences that are interracial are more likely to have a story published about them (again, at the lower $p<.05$ level). For the Cincinnati Enquirer, the only significant variable is that the death sentence is local (odds ratio $=384.738, \mathrm{p}<. \mathrm{OOI}$ ). What is interesting is that the odds ratio for this variable is much larger for the Enquirer than for the Plain Dealer, which supports the earlier contention that coverage in the Enquirer is overwhelmingly local-centric.

Finally, analyses were performed to determine which factors were associated with continuing coverage of certain death sentences. Table 5 provides these results. For Cleveland's Plain Dealer, again, local death sentence cases received more coverage than non-local cases $(b=\mathrm{IO} .877$, $\mathrm{p}<. \mathrm{OOI})$. Additionally, death sentences featuring male defendants received less coverage than cases featuring female defendants $(b=$ 16.962, pc.01). This is not surprising, however, since cases involving female defendants were (and still are) an anomaly, which likely increased interest in these cases. Additionally, death sentences involving younger defendants received less coverage than cases involving older defendants, but this is only significant at the lower pC.05 level. For Cincinnati's Enquirer, local death sentence cases received more coverage than non-local cases $(b=\mid 8.724, p<.0 O I)$. As with the Plain Dealer, cases involving male defendants received less coverage than female defendants $(b=-18.685, p C .01)$. The Enquirer 
published fewer stories in cases involving non-strangers $(b=-5.038$, F.01) and more stories in cases involving multiple victims ( $b=5.237$, pC.01). These variables were not significant in the Plain Dealer analysis. In Ohio, non-stranger homicides are the minority, so it is not surprising that the newspaper would not cover these as extensively. On the other hand, homicides with multiple victims, though a minority of death sentences, are covered more extensively than single-victim homicides. As with the gender of the defendant, cases involving atypical characteristics result in more extensive coverage.'

Table 5

Factors Associated With Continuing Coverage

\begin{tabular}{lcccc}
\hline \multicolumn{1}{c}{ Cleveland Plain Dealer } & & & & \\
\cline { 1 - 1 } \cline { 5 - 5 } Defendant Race & & b & S.E. & T-value \\
Defendant Gender & & -1.742 & 3.717 & -.469 \\
Defendant Age $<25$ & -16.962 & 8.013 & $-2.117^{* *}$ \\
Victim Race & -4.401 & 2.340 & $-1.881^{*}$ \\
Victim Gender & -1.457 & 3.831 & -.380 \\
Victim Age $<12$ or $>70$ & & -3.262 & 2.255 & -1.446 \\
Relationship & 2.924 & 2.627 & 1.113 \\
Weapon Used & -3.639 & 2.242 & -1.881 \\
Multiple Victims & -3.170 & 2.261 & -1.402 \\
Felony Circumstances & 2.753 & 2.545 & 1.082 \\
Local Homicide & 2.478 & 2.814 & .880 \\
Interracial Homicide & 10.877 & 2.271 & $4.790 * * *$ \\
Constant & 1.238 & 3.720 & .333 \\
& 23.777 & 8.833 & 2.692
\end{tabular}


Table 5 cont'd

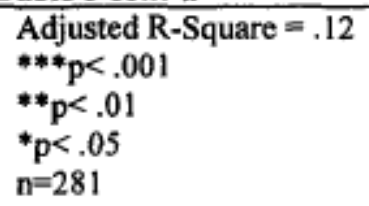

\begin{tabular}{|c|c|c|c|}
\hline Cincinnati Enquirer & \multirow[b]{2}{*}{ b } & \multirow[b]{2}{*}{ S.E. } & \multirow[b]{2}{*}{ T-value } \\
\hline & & & \\
\hline Defendant Race & .010 & 2.836 & .004 \\
\hline Defendant Gender & -18.685 & 5.914 & $-3.159^{* *}$ \\
\hline Defendant Age $<25$ & -1.405 & 1.714 & -.820 \\
\hline Victim Race & -1.727 & 2.889 & -.598 \\
\hline Victim Gender & -1.435 & -1.677 & -.856 \\
\hline Victim Age $<12$ or $>70$ & -2.476 & 1.916 & -1.292 \\
\hline Relationship & -5.038 & 1.630 & $-3.090^{* *}$ \\
\hline Weapon Used & 2.278 & 1.664 & 1.369 \\
\hline Multiple Victims & 5.237 & 1.842 & $2.843^{* *}$ \\
\hline Felony Circumstances &,- 146 & 2.022 & -.072 \\
\hline Local Homicide & 18.724 & 1.775 & $10.551^{* * *}$ \\
\hline Interracial Homicide & 1.987 & 2.871 & .692 \\
\hline Constant & 20.759 & 6.639 & 3.127 \\
\hline $\begin{array}{l}\text { Adjusted R-Square = .34 } \\
* * * p<.001 \\
* * \mathrm{p}<.01 \\
{ }^{*} \mathrm{p}<.05 \\
\mathrm{n}=281\end{array}$ & & & \\
\hline
\end{tabular}

\section{DISCUSSION AND IMPLICATIONS}

The preceding analyses were conducted to gauge how two different urban newspapers in the same state covered death sentence cases that took place in the state over a 24-year time period. Both newspapers cover rather large metropolitan areas; these areas account for the majority of death sentence cases under study. In addition, these newspapers serve communities that are rather distinct from one another and the newspapers themselves are characterized as catering to different political audiences. General results indicated the same pattern of coverage as reported in Chermak (1998), Peelo et al. (2004) and Johnstone, Hawkins, and Michener (1994) - not all homicides are treated the same. Cleveland's Plain Dealer provided more coverage of non-local death sentences relative to Cincinnati's Enquirer, although a good portion of these non-local death sentences were still ignored by the Plain Dealer. Additionally, the Plain Dealer published more of these stories in the earlier sections of the paper and provided more coverage of the case process. Regarding local death sentences, both 
newspapers increased their coverage, but the Enquirer seemed to increase its local coverage quite dramatically. Although, again, the Plain Dealer continued to publish stories in the earlier sections of the paper, the Enquirer published more stories, even though there were fewer death sentences imposed in Cincinnati's metro area.

Regarding the regression analyses, it is apparent that the Enquirer is more local-centric in its coverage of death sentence cases. The Enquirer also published more stories on death sentences involving multiple victims - which only constituted 27 percent of death sentence cases during this time - and those involving strangers - which constituted 54 percent of cases during this time. Both of these traits are atypical of homicides in general (see generally, Bureau of Justice Statistics, 2004) and one is atypical of Ohio death sentences in particular (multiple victims). Readers may not necessarily know that these traits are uncommon yet, due to more coverage, readers may perceive that they are more prevalent than they are.

Regarding the local-centric coverage, it seems as if the Cincinnati criminal justice system and Cincinnati media focus quite a bit on local crime in general. For example, local police established a unique program that sends text messages, e-mails, and faxes to residents when crimes occur in their neighborhoods. In addition, an innovative segment on local Cincinnati television stations featuring the "Wheel of Justice" asks viewers to assist in tracking down the area's 50 most wanted criminals. Going beyond "Crime Stoppers," the program attracts many viewers and, according to Cincinnati's mayor, the segment ' $b$. . . figured out a way to capture viewers' attention and allowed that viewer to become a participant in fighting crime" in their city (Coolidge, 2006). Thus, it would appear that a heavy focus on local crime is good for business.

Due to the racial problems in Cincinnati over the years, it is somewhat surprising that the race variables in the Enquirer analyses were not significant, given the news media's complicity in constructing "crime problems" or "crime fears" (see generally, Barak, 1994). Two race variables were marginally significant in the Plain Dealer analyses - race of defendant and interracial homicide. It could be argued that a focus on death sentence cases featuring an interracial element, which were rare during this time period, is an effort to sensationalize such incidents. However, since death sentences involving white defendants (constituting the majority of death sentences) were also more likely to be covered by the Plain Dealer, it casts a shadow over the previous assumption, presumably since black offender-white victim homicides would be considered more newsworthy (see Wortley, Hagan, and MacMillan, 1997). Although previous research has shown a race of 
defendant or race of victim effect regarding media coverage of homicides and other crimes (see generally, Sorenson, Manz, and Berk, 1998; Johnstone, Hawkins, and Michener, 1994), the narrow focus of this study (homicides that resulted in a death sentence) may have played a role in the non-significant results for these variables. Most homicides in Ohio involve black defendants and black victims, yet these homicides are least likely to result in a death sentence (see Williams and Holcomb, 2004). This perhaps indicates that prosecutors are reluctant to pursue the death penalty for racial or other case-based reasons or that judges or juries neglect to impose the death penalty in such cases. Newspaper coverage of death sentence cases is perhaps reflective of WHO the prosecutor views as worthy of a death sentence. If those who kill black victims are not deemed by prosecutors as eligible for a death sentence, there are fewer of them to report about. It may very well be that newspaper coverage of all homicides in Ohio will reflect a racial bias in coverage, but there appears to be no such effect when examining coverage of death sentence cases in particular.

The present study hoped to provide another dimension in the literature that focuses on media coverage of crime and justice issues, particularly the death penalty. While it is supported that television and newspaper coverage of these issues is plentiful and, in most cases, sensationalistic, it cannot be assumed that all coverage is equal, especially newspaper coverage. Local television stations are usually not considered biased, but local newspapers are implicated in this, even if the newspapers do not purposefully reflect any sort of bias. The present study attempted to explore how two newspapers in the same state treated the same types of cases. Results indicated that there are differences in the way local newspapers cover these cases. As mentioned previously, Cincinnati's Enquirer provides coverage that is overwhelmingly local, tending to overlook death sentences cases occurring outside the local coverage area. In addition, both newspapers had no coverage of a handful of local death sentence cases. This seems extraordinary, since these cases are considered the worst of the worst AND they feature local interest. The audience that is reading these newspapers only gets the information that the newspapers provide. How, then, can the audience make informed decisions about such issues if the public does not get all of the information? Finally, audiences that are exposed to differential coverage of the same issue may reach totally different conclusions about that issue. Therefore, when utilizing newspaper coverage to gauge public opinion, attitudes, or even a deterrent effect of the death penalty, it is important for future research to consider that newspaper coverage is not the same and that areas, even within the same state, may not be exposed to the same type of coverage. 


\section{NOTES}

1. In both cities, there was one case that involved quite extensive coverage, which could result in skewed results. In the Cleveland area, coverage of a cult killing received continuously extensive coverage in the Plain Dealer; in the Cincinnati area, a tri-state killing spree also received continuously extensive coverage in the Enquirer. Analyses were run with these cases included and omitted; the results were not statistically or substantively different.

\section{REFERENCES}

Audit Bureau of Circulations (2004). Reader Pofile: The Plain Dealer. Retrieved January 6, 2006 from:

http://abcas3.accessabc.com/readerprofile/released.asp

Bailey, W. (1990). "Murder, Capital Punishment, and Television: Execution

Publicity and Homicide Rates." American Sociological Review 55, 628-633.

Bailey, W. (1998). "Deterrence, Brutalization, and the Death Penalty: Another Examination of Oklahoma's Return to Capital Punishment." Criminology 36, 711-733.

Barak, G. (1994). "Between the Waves: Mass-Mediated Themes of Crime and Justice." Social Justice 21, 133-147.

Bureau of Justice Statistics (2004). Homicide Trends in the United States. Washington, DC: U.S. Department of Justice.

Chermak, S. (1998). "Predicting Crime Story Salience: The Effects of Crime, Victim, and Defendant Characteristics." Journal of Criminal Justice 26, 61-70.

Chermak, S. (1995). Victims in the News: Crime in the American News Media. Boulder, CO: Westview.

Chiricos, T., Eschholz, S., and Gertz, M. 91997). "Crime, News, and Fear of Crime: Toward an lentification of Audience Effects." Social Problems 44, 342357.

Citizens for Civil Renewal (2001). Cincinnati Metropatterns. Retrieved January 6, 2006 from www.citizenscivicrenewal.org/metro_soc.htm

City Beat. (2000, October 5-11). "GOP Kicks Ass." Retrieved January 6, 2006 from www .citybeat.com/2000-10-05/cover.shtml.

Coolidge, S. (2006, June 8). "Show Puts Spin on Stopping Crime." USA Today. Retrieved June 20, 2006 from www.usatoday.com/news/nation/2006-06-08- 
crlme-show_x.htm

Duwe, G. (2000). "Body Count Journalism: The Presentation of Mass Murder in the News Media." Homicide Studies 4, 364-399.

Fan, D., K. Keltner, and R. Wyatt (2002). "A Matter of Guilt or Innocence: How News Reports Affect Support for the Death Penalty in the United States." International Journal of Public Opinion Research 14, 439-452.

Franklin, B. ( 1999). Social Policy, the Media, and Misrepresentation. New York: Routledge.

Free Press (2004, November 22). "How the Ohio Election Was Rigged for Bush." Retrieved January 6, 2006 from www.freepress.org.

Fox, J. and J. Levin (1998). "Multiple Homicide: Patterns of Serial and Mass Murder." In M. Tonry (ed.), Crime and Justice 23: 99.407-455). Chicago: University of Chicago Press.

Gerbner, G. and L. Gross (1980). "The Violent Face of Television and Its Lessons." In E. Palmer and A. Dorr (eds.), Children and the Faces of Television (pp.149-162). New York: Academic Press.

Gilliam, F. and S. Iyengar (2000). "Prime Suspects: The Influence of Local Television News on the Viewing Public." American Journal of Political Science 44, 560-573.

Graber, D. (1980). Crime News and the Public. New York: Praeger.

Gross, S. and R. Mauro (1989). Death and Discrimination: Racial Disparities in Capital sentencing. Boston: Northeastern University Press.

Haney, C. S. and Greene (2004). "Capital Constructions: Newspaper Reporting in Death Penalty Cases." Analyses of Social Issues and Public Policy 4, 129150.

Holley, J. (1996). "Should the Coverage Fit the Crime?" Columbia Journalism Review 35, 27-33.

Hulsey, L. (2001, April 28: Al). "Survey: Cincy Cops More Likely to Kill than in 7 Comparable Cities." Dayton Daily News. Retrieved January 6, 2006 from LexisNexis Academic database.

Johnstone, J., D. Hawkins, and A. Michener (1994). "Homicide Reporting in Chicago Dailies." Journalism Quarterly 71, 860-872

Lundman, R. (2003). "The Newsworthiness and Selection Bias in News about 
Murder: Comparative and Relative Effects of Novelty and Race and Gender Typifications on Newspaper Coverage of Homicide." Sociological Forum 18, 357-387.

Newspapers First (2004). Cincinnati, OH Circulation Data. Retrieved January 6, 2006 from www.newspapersfirst.com/MICirCinn.html

Peelo, M., B. Francis, K. Soothill, J. Pearson, and E. Ackerley (2004).

"Newspaper Reporting and the Public Construction of Homicide." British Journal of Criminology: 44, 256-275.

Peterson, R. and W. Bailey (1994). "Murder, Capital Punishment, and Deterrence: A Review of the Evidence and an Examination of Police Killings." Journal of Social Issues 50, 53-74.

Peterson, R. and W. Bailey (1991). "Felony Murder and Capital Punishment: An Examination of the Deterrence Question." Criminology 29, 367-395.

Roberts, J. and A. Doob (1990). "News Media Influences on Public Views on Sentencing" Law and Human Behavior 14, 451-468.

Sorenson, S., J. Manz, and R. Berk (1998). "News Media Coverage and the Epidemiology of Homicide." American Journal of Public Health 88, 15101514.

Sotirovic, M. (2003). "How Individuals Explain Social Problems: The Influences of Media Use." Journal of Communication 53, 122-137.

Stack, S. (1987). "Publicized Executions and Homicide, 1950-1980." American Sociological Review 52, 532-540.

Stolzenberg, L. and S. D' Alessio (2004). "Capital Punishment, Execution Publicity, and Murder in Houston, Texas." Journal of Criminal Law and Criminology, 94, 351-380.

Surette, R. (1998). Media, Crime, and Criminal Justice: Images and Realities. Belmont, CA: Wadsworth Publishing.

United States Census Bureau (1997). American Housing Survey for the Cleveland Metro Area: 1996. Retrieved January 6, 2006 from www.census.gov/prod/3/97pubs/hl 709645.pdf

United States Census Bureau (2000). American Housing Survey for the Cincinnati Metro Area: 1998. Retrieved January 6, 2006 from www.census.gov/prod/2000pubs/hl 70-98-23.pdf

Williams, M. and J. Holcomb (2004). "The Interactive Effects of Victim Race 
and Gender on Death Sentence Disparity Findings." Homicide Studies 8, 350376.

Wortley, S., J. Hagan, and R. Macmillan (1997). "Just Des(s)erts? The Racial Polarization of Perceptions of Criminal Injustice." Law and Society Review 31, 637-676.

Yanich, D. (2001). "Location, Location, Location: Urban and Suburban Crime on Local TV News. "Journal of Urban Affairs 23, 221-241. 